\title{
The Contribution of Grade Point Average (GPA), Microteching Practice Achievement and Motivation to be a Teacher on the Students' Teaching Practicum Achievement
}

\author{
M. Sulthon Masyhud ${ }^{1}$, Zakiyah Tasnim², Misno A. Latif ${ }^{1}$ \\ ${ }^{I}$ Department of Elementary School Teacher Education, University of Jember, Indonesia \\ ${ }^{2}$ Department of English Language Education, University of Jember, Indonesia \\ *Corresponding Author: M. Sulthon Masyhud, Department of Elementary School Teacher Education \\ University of Jember, Indonesia
}

Received Date: 11-06-2017

Accepted Date: 16-06-2017

Published Date: 22-06-2017

\section{ABSTRACT}

This research was to investigate the contribution of GPA, microteaching practice achievement, motivation to be a teacher, collectively or separatedly, on the teaching practicum achievement of the students of Faculty of Teacher training and Education of Jember university. To gain the research objective, ex-post facto research design was applied. Quota random sampling was used to select 60 students as the research sample of 209 students ofthe Faculty of Teacher Training and education The University of Jemberas the research poulation. Observation, questionnaire, and documentaion were used to collect the data. Multiple regression and partial correlation analysis were applied to analyse the collected data. The analysis results showed that the students' GPA, microteaching practice achievement, motivation to be a teacher, being together or separated, had high contribution to the teaching practicum achievement.

Keywords: Grade Point average (GPA), microteaching practice achievement, motivation to be a teacher, teaching practicum achievement

\section{INTRODUCTION}

The education of prospective teachers in this globalization era is directed at professional Teacher Education and has a high competitive power. In an effort to produce highly qualified and competent professional teacher candidates, Competence Based Teacher Education (CBTE) has been implemented in several Institutes of Teacher Training and Education, including the Faculty of Teacher Training and Education of The University of Jember. The CBTE provides the emphasis on the role of teaching practicumwhich is not only a formal demand for teacher candidates to pass, but it is also the target and the benchmark of teacher education success (Depdikbud, 1998; Elam, 2001; Masyhud \& Tasnim, 2016a).

The achievement of these competencies in CBTE is done gradually through various activities, starting from: 1) theoretical activities, ie in the form of lecture activities in the campus both related to the field of study to be taught, as well as related to the field of educational skills; 2) limited practice activities, such as "microteaching" activities, or limited teaching practice conducted on campus; and 3) teaching practicum at the schools(Brown, 2009; Teaching Practicum and Microteaching Unit, 2010).

The three stages of activity are a series and can not be separated from one another. In addition, the three are also hierarchical stages. Theoretical activities must be done before doing microteaching practice, and teaching practicum must be done after doing microteaching practice. The first stage of theoretical activities concern on understanding about the subject matter, theories of education, teaching method, media, evaluation and basic teaching skills. In the second stage, teaching practice on campus in the form of microteaching is done. Microteaching practice may vary according to the condition, facilities, and the readiness of the supervisor. It can be done with real students or peer teaching. Itcan also be for practicing isolated basic teaching skill or practicing integrated basic teaching skills, covering the skill of set induction and closure, giving explanation, giving and responding questions, giving reinforcement, giving stimulus variation, 
classroom management, guiding small group discussion (Depdikbud, 1992; Masyhud \& Tasnim, 2009; Teaching Practicum and Microteaching Unit, 2010; Microteaching Laboratory Faculty of Teacher Training and Education The University of Jember, 2010).

Microteaching can be done by applying simple instruments such as using observation checklist for recording the students' performance on practicing basic teaching skills. It can be done by using more modern instrument, such as video, to record the students' performance on practicing basic teaching skills. From the result of video recording, the students can learn their strengths and weaknesses Waskito, 2009). After that, they practice again to maintain their strengths and to minimize their weaknesses. So, the students can monitor their own progress in developing their basic teaching skills.

Practicing isolated basic teaching skill in microteaching is important before practicing integrated skills. It is easier to observe the strengths and weaknesses done by the students while they practice isolated skill than integrated skills. After knowing their weaknesses in isolated skill, the students are invited to practice again to minimize the weaknesses. When it is sure that the students are good in performing isolated basic teaching skill, they are invited to practice integrated basic teaching skills in campus (Masyhud \& Tasnim, 2009; Teaching Practicum and Microteaching Unit, 2010; Sulthon, 2011). After that the students should do teaching practicum at schools as the final stage to establish their teaching competency

Infact, that the establishment of teacher candidates' teaching competency is not as simple as described above. Many factors influence the success in theestablishment of teacher candidates' teaching competency. The previuos research results showed that there was a significant correlation between the students' (teacher candidates') perception for being teacher on the students' teaching practicum achievement (Sulthon, 2009; 2010). Onother research found that the students' microteaching ractice achievement was influenced by the supervisor' treatment in the practice. Here, the treatment referred to the practice model and supervision system applied (Loughtin \& Mouulton, 1995; Sulthon, 2010). Similarly, the research conducted by Tasnim (2016) found that the students' motivation to be an English teacher at Faculty of Teacher Training and education, the University of Jember had significant correlation with the students'teaching practice achievement

Furthermore, the results of research conducted at Faculty of Teacher Training and education. TheUniversity of 11 March Solo found evidence, that the achievements ofGeneral Course, Teaching Learning Process cours, and Special Study Subject Course had no significant correlation with the students' ability, while the achievement of Special Study Subject Course and learning motivation has a significant correlation with the students' teaching ability (Masyhud \& Tasnim, 2009). Such matters indicated that the problem of teaching competency establishment is complex. Therefore, this research was needed to be conducted to reveal it more deeply.

Based on the ideas raised in the previous section, the main problem of this research could be be formulated as follows: Did the theoretical achievements $(\mathrm{GPA}=$ Grade Point Average $)$, microteaching practice achievement, and the students' motivation to be a teacher have a positive significant contribution the students' teaching practicum achievement?

Attempts to obtain the answers of the problems above were also regarded as the objective of this research. This research aimed to confirm the theory, which suggests that learning outcomes are influenced by internal and external factors at once. If the theory is true, then it was continued to know how far the contribution of the students' theory achievement, microteaching practice achievement, and their motivation to be a teacher that is considered as a driving force to the learning activities on the students' teaching practicum, as the indicator of the successful establishment of the students' teaching performance.

The results of this research are expected to be useful for the development of microteaching training programs, especially in the microteaching laboratory of Faculty of Teacher Training and Education The University of Jember. In addition, the results of this research can also be used as the inputs for the improvement of teaching practicum programs, especially at Teaching Practicum Program Unit of Faculty of Teacher Training and education The University of Jember. Then for other researchers in education, the results of this study can be used as an input to conduct further research about teacher candidates' teaching 
competency. At last this research result can give contribution to strengthen the literature review and empirical evidence of the research background.

The hypothesis of this research can be formulated as follows: 1) collectively the whole independent variables consisting of theory achievement (GPA), the microteaching practice achievement, and motivation to be a teacher had a positive contribution to the students' teaching practicum achievement, 2) each independent variable consisting of theory achievement (GPA), the microteaching practice achievement, and motivation to be a teacher had a positive contribution to the students' teaching practicum achievement.

\section{RESEARCH METHODS}

This research used Ex-Post Facto Research design (Kerlinger, 1995; Masyhud \& Tasnim, 2016). This design was chosen because this research was to reveal the research data which at the time of this research was done, the event had passed, so this research was revealing the fact that had been going on (Kerlinger, 1995; Arikunto, 2009; Masyhud \& Tasnim, 2016b). The disclosure of these facts is done through searching, identifying, and collecting data, and then analyzing them.

The research area was the Faculty of Teacher Training and education The University of Jember. The research population was all the students who took microteaching course in odd semester and teaching practicum course in the even semester of 2015/2016 at the Faculty of Teacher Training and education The University of Jember. Then the research sample was 40 students taken from the research population of 209 students. Sampling was done by "quota randum sampling" technique, where 8 students were taken from each study program. The sample was five study programs at Faculty of Teacher Training and education - Jember Universityconsisting of English Education, Indonesian Education, Biology Education, Mathematics Education, and Physics Education study programs; while Economics and History education programs were not included in the research popoulasi, because they did not enroll microteaching course in the odd semester of $2015 / 2016$. Then the respondentswere taken randumly with lottery.

Furthermore, the research instruments to collect the data were:1) documentation and 2) questionnaire. Documentation was used primarily to collect all data about GPA and student microteaching achievement; while the questionnaire was used to get data the students'motivation to be a teacher. After that, the collected data wre analysed by using: 1) multiple regression analysis and 2) partial correlation analysis (Tuckman, 1998; Masyhud \& Tasnim, 2015).

\section{RESEARCH RESULT AND DISCUSSION}

The results of multiple regression analysis done by SPSS with 40 subjects, showed regression coefficient obtained as follows: a1 $=2,5864$, a2 $=0.4201, \mathrm{a} 3=0.3463$ with a constant number of 16.2440. With these results, the regression equation became as follows: $\mathrm{Y}=2.5864 \mathrm{X} 1+$ $0,4201 X 2+0,3463 X 3+16,2440$. Standard Error for the regression equation was found to be $=2,062$; While the multiple correlation $(\mathrm{R})$ was obtained at $=0.865$. The coefficient was determinant (R-Sequare) of the regression equation was found to be $=0.748$. The 'F-reg' value for the multiple regression equation was 35.761. The 'F-reg' value was greater than the 0.05 significant level for Degree of Freedom 3.36 , which was 2.86 . It can be concluded that the regression equation obtained was significant.

Since the results of the analysis before being used to test the hypothesis, it must first meet the requirements of linearity test. The linearity test was done by finding the Standard Error of $Y$ for $\mathrm{X}$, then compared with the average sum of squares for the residue. If the variance was smaller or equal to the sum of the squares of the residue, then the multiple regression equation obtained was linear. However, if the variance was greater than the sum of the squares of the residue, then the multiple regression equation obtained was non-linear. The result of data analysis showed that standard error of estimation obtained was equal to $=2.062$ and after squared to $=4,252$. This number proved to be much smaller than the sum of the squares of the residue, which is $=153,027$. Thus it could be concluded that the multiple regression equation obtained was linear.

From the two kinds of test, it was known that the multiple regression equation obtained had fulfilled the requirement to serve as the basis for predicting every independent variable, theory achievement or GPA (X1), microteaching practiceachievement $(\mathrm{X} 2)$ and motivation to be ateacher (X3) on the dependent variable (Y), and thus it had fulfilled the requirements also for testing the research hypothesis. 
From the analysis result of hypothesis testing of number 1, it could be concluded that all independent variable $\mathrm{X}$ consisting of theory achievement or GPA (X1), microteaching practiceachievement $(\mathrm{X} 2)$ and motivation to be ateacher (X3) had positive contribution to the students' teaching practicum achievement at the Faculty of Teacher Training and educationJember University, because the result of multiple correlation obtained by $=0.865$ shows bigger than the null number.

The amount of contribution of all independent variables together against the dependent variable (students' teaching practicum achievement was equal to $74.821 \%$. The number was obtained by squaring the multiple correlation (R). With the influence, it can be said, that as much as $74.827 \%$ part of the achievement of students' teaching practicum achievement at the Faculty of Teacher Training and Education-Jember Universitywas influenced by the independent variables collectively (theory achievement or GPA, microteaching practiceachievement and motivation to be ateacher ). From the fact it could also be claimed, that there was still as much as $25,173 \%$ part of the students' teaching practicum achievement influenced by other variables besides the three independent variables being investigated. The variables were likely to be related to students' intelligence (IQ), students' persistence, students' readiness, training atmosphere, and supervison guided by lecturers orteachers, as mentors, during teaching practicum at schools. However, the contribution of these variables to the students'teaching practicum achievement still needed to be investigated further.

The next analysis was partial correlation analysis. This analysis done to get correlation between each of the independent variable $(\mathrm{X})$, consisting of GPA (X1), microteaching practice achievement (X2), and students' motivation to be a teacher (X3) and the student' teaching practicum achievement $(\mathrm{Y})$. The result of the partial correlation was then used as a basis to test the null hypothesis of the research number 2 and to determine which one of the $\mathrm{X}$ variables actually acted as the predictors of the student' teaching practicum achievement $(\mathrm{Y})$ and which one only served as pseudo predictor.

The results of partial correlation calculations showed that partial correlation between GPA and teaching practicum achievement $\left(\mathrm{r}-\mathrm{parX}_{1} \mathrm{Y}\right)$ was obtained at $=0.382$; Partial correlation between microteaching practice achievement and teaching practicum achievement ( $r-p a r \mathrm{X}_{2} \mathrm{Y}$ ) $=0,665$ whereas partial correlation between motivation to bea teacher and teaching practicum achievement $\left(r-p a r X_{3} Y=0,472\right)$ The three partial correlation coefficients showed greater than r-table at the level of significance 0.05 with $\mathrm{db} .39$, that was 0.312 .

Based on the three kinds of partial correlations, itcould be concluded that the three independent variables, which consist of: 1) achievement in theory (GPA), 2) achievement in microteaching practice and 3) students' motivation to be a teacher, had positive contribution on the teaching practicum achievement of the students of at the Faculty of Teacher Training and Education The University of Jember. Thus, each of the three variables separately can also be used as the predictor of the students' teaching practicum achievement at the Faculty of Teacher Training and Education The University of Jember

The amount of effective contribution separately of each of the three independent variables to the teaching practicum achievement of the students of the Faculty of Teacher Training and Education The University of Jember was: 1) GPA contributes $15,469 \%$, 2) Achievement of microteaching practice $33,590 \%, 3$ ) and motivation to be a teacher $25.768 \%$. Thus, the total effective contribution of the three independent variables on the students' teaching practicum achievement was $74.827 \%$.

Based on the results of hypothesis testing and discussion mentioned above, it could be presented several findings as follows:

1. The achievement of the teaching practicum of the students of the Faculty of Teacher Training and Education-The University of Jember could be predicted, either collectively or separately by the independent variables consisting of achievement of theory (GPA), achievement of micoteaching practice, and students' motivation to be a teacher.

2. Because collectively or separately, all the control variables showed an effect on the achievement of teaching practicum, then the three independent variables, either collectively, or individually, all can play a significant role as predictors to predictthe students' teaching practicum achievement at of the Faculty of Teacher Training and Education The University of Jember. 
3. Another finding which can be put forward based on the results of this research analysis was that:

a. The higher the achievement in theory (GPA) that students got, the higher their achievement in teaching practicum.

b. The high achievement of microteaching practice obtained by the students, followed by the higher their achievement in teaching practicum.

c. Similarly, the higher the students' motivation to be a teacher, the higher their achievements in teaching practicum.

d. If the contribution of all independent variables collectively on the achievement of the students' teaching practicum achievement at of the Faculty of Teacher Training and Education The University of Jember reached as much as $=74,827 \%$, then there was still about $25,173 \%$ of students' teaching practicum achievement influenced by other variables besides the three variables studied. Therefore, it is needed to conduct a further research, in order to get a clearer picture of the factors affecting students' teaching practicum achievement.

\section{CONCLUSIONS AND RECOMMENDATIONS}

Based on the results of data analysis and discussion as presented in the previous section, the following points could be concluded as follows.

1. Collectively, all the independent variables consisting of theory achievement (GPA), microteaching practice achievement, and students' motivation to be a teacher, had a positive contribution to the students' teaching practicum achievement at of the Faculty of Teacher Training and Education The University of Jember. The effective contribution of the three independent variables on the achievement of students' teaching practicum reached $74.827 \%$.

2. Separately, each independent variable had a different contribution to the students' teaching practicum achievement. GPA variable contributed $15.469 \%$; microteaching practice achievement variable was $33,590 \%$, and students' motivation to be a teacher variable was $25,768 \%$.

3. Thus, the students' teaching practicum achievement at the Faculty of Teacher
Training and Education The University of Jember was predicted, either collectively or separately, by the independent variables consisting of theory achievement (GPA), microteaching practice achievement, and students' motivation to be a teacher

Based on the research results above, it can be put forward some suggestions as follows.

1. To the Microteaching Laboratory Head. The results of this study showed that the results of microteaching practice had the highest contribution to the results of students' teaching practicum compared to the other two variables. Therefore, the microteaching laboratory manager is suggested to always develop microteaching practice programs, in order to achieve the optimal training achievement.

2. To the headof the Teaching Practicum UnitProgram. From the results of the research finding, that students' teaching practicum achievement was influenced by the three independent variables consisting of theory achievement (GPA), microteaching practice achievement, and students' motivation to be a teacher, the head of the Teaching Practicum Unit, especially at the Faculty of Teacher Training and Education The University of Jember should consider the coaching of pre- teaching practicum students in cooperation with the microteaching laboratory manager. In addition, he should always develop motivation to the students, as teacher candidates, to have positive insight into the teaching profession.

3. To other researchers. The contribution of all independent variables as a whole to the students' teaching practicum achievement at the Faculty of Teacher Training and Education- University of Jember reached as much as $=74,827 \%$, then there was still about $25,173 \%$ of the students' teaching practice achievement influenced by other variables besides the three variables studied. Threfore, other researchers who are interested in investigating the problems of students' teaching practicum are suggested to conduct further reasearch on other variable in order to obtain a clearer picture of the factors that affect students' teaching practicum achievement.

\section{ACKNOWLEDGEMENT}

We gratefully acknowledge the support from FKIP - University of Jember of year 2017. 
The Contribution of Grade Point Average (Gpa), Microteching Practice Achievement and Motivation to be a Teacher on the Students' Teaching Practicum Achievement

\section{REFERENCES}

[1] Arikunto. Suharsimi, 2009. Research Procedure: A Practice Approachrosedur Penelitian;. Jakarta : Literacy Establishment.

[2] Brown, George, 2009. Microteaching: A Programme of Teaching Skills. London : Mathuen.

[3] Depdikbud, 1998. Developmental educational Project Book II : The Implementation of Teaching Practicum Jakarta : General Directorate of Higher Education

[4] Depdikbud, 2009. Microteaching. Jakarta : General Directorate of Higher Education; Higher education Development Project.

[5] Elam, S., 2011. Performance-Based teacher Education : What is the State of The Art? Washington DC.: American Association of College For Teacher Education.

[6] Kerlinger, Fred, N., 1999. Foundation of Behavioral research. New York : Holt, Rinehart and Winston, Inc.

[7] Laughlin \& J. Moulton, 1995. Evaluation of Performance Training Methods : A Manual of Teaching Trainer. New York: UNESCO.

[8] Masyhud, M. Sulthon \& Zakiyah Tasnim, 2009. Microteaching Management. Yogyakarta: Laksbang Press.

[9] Masyhud, M. Sulthon \& Zakiyah Tasnim, 2016a. Educational Profession Management. Yogyakarta: The Gift of the Universe.

[10] Masyhud, M. Sulthon \& Zakiyah Tasnim, 2016b. Educational Research Methodology for Teacher Candidate and Educational Practicant: Theory and Practice. Jember: The Institution of Management Development and Educational Profession Developmnet

[11] Masyhud, M. Sulthon, 2015. Statistical data Analysis for Educational Research. Jember: The Institution of Management Development and Educational Profession Development.

[12] Microteaching Laboratory Faculty of Teacher Training and Education, The University of Jember, 2010. The Guide-line of Microteaching Implementation for the Students of Faculty of Teacher Training and Education, the University of Jember. Jember: Microteaching Laboratory Faculty of Teacher Training and Education The University of Jember.
[13] Sulthon, M., 2009. The Correlation between Teacher Candidates' Expectation for being Teacher and TheirTeaching Practicum Achievement penelitian. Jember : Research Centre of The University of Jember.

[14] Sulthon, M., 2010. The Effect of Treatment in Microteaching Practice on Microteaching Practice Achievement of the students of Faculty of Teacher Training and Education, the University of Jember. Jember : Research Centre of The University of Jember.

[15] Sulthon, M., 2011. Microteaching Concept and the Implementation Procedure. Jember : Faculty of Teacher Training and Education, the University of Jember.

[16] Tasnim, Zakiyah, 2016. Motivation for Being An English Teacher of the Diploma III Students of Faculty of Teacher Training and Education, the University of Jember. Jember: the University of Jember

[17] Teaching Practicum and Microteaching Unit of Faculty of Teacher Training and Education, the University of Jember, 2010. Teaching Practicum Guide-book For Students Faculty of Teacher Training and Education, the University of Jember. Jember : the University of Jember.

[18] Tuckman, Bruce, W., 1998. Conducting Educational Research. New York : Harcourt BaseJavanovich, Inc.

[19] Waskito Tjiptosasmito, 2009. Microteaching Technique as one of Learning Strategies Emphasizing on Performance. Jakarta : General Directorate of Higher Education, Higher Education

\section{AUTHOR'S BIOGRAPHY}

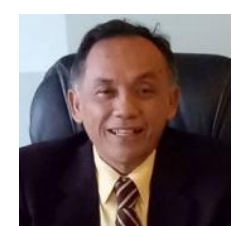

M. Sulthon Masyhud, he was graduated for doctorate degree in education managament. Since 2008, I was awarded for Professor in education management. I have been teaching in the Faculty of Teacher Training and Education the University of Jember Since 1982. I have been supervising undergraduate and postgraduate students more than 1500 students since my carier to be a lecturer. Now my research interest mainly studies about elementary teacher education sector.

Citation: M. Sulthon, Masyhud et al. "The Contribution of Grade Point Average (GPA), Microteching Practice Achievement and Motivation to be a Teacher on the Students' Teaching Practicum Achievement." International Journal of Research in Humanities and Social Studies, vol 4, no. 4, 2017, pp. 2227.

Copyright: (c) 2017 M. Sulthon Masyhud. This is an open-access article distributed under the terms of the Creative Commons Attribution License, which permits unrestricted use, distribution, and reproduction in any medium, provided the original author and source are credited. 